\title{
Assessment of Heavy Metal Pollution in the Sediment of the Main Tributaries of Dongting Lake, China
}

\author{
Jinying $X u^{1,2}$, Yuwei Chen ${ }^{1}$, Lilin Zheng ${ }^{1,2}$, Baogui Liu ${ }^{1,2}$, Jinfu Liu ${ }^{1,2}$ and Xiaolong Wang ${ }^{1, *}$ \\ 1 State Key Laboratory of Lake Science and Environment, Nanjing Institute of Geography and Limnology, \\ Chinese Academy of Sciences, Nanjing 210008, China; xujinying14@mails.ucas.ac.cn (J.X.); \\ ywchen@niglas.ac.cn (Y.C.); 15623118778@163.com (L.Z.); baogui19900525@gmail.com (B.L.); \\ ljinfu2018@126.com (J.L.) \\ 2 University of Chinese Academy of Sciences, Beijing 100049, China \\ * Correspondence: wangxl@niglas.ac.cn; Tel.: +86-25-8688-2115
}

Received: 13 July 2018; Accepted: 6 August 2018; Published: 10 August 2018

\begin{abstract}
Heavy metal pollution in sediment is one of the most serious problems in water bodies, including rivers, which can cause secondary pollution when environmental conditions change. In this study, surface sediment samples collected from the four main tributaries of Dongting Lake (i.e., Xiangjiang River (XR), Zishui River (ZR), Yuanjiang River (YR), and Lishui River (LR)) were analyzed for concentrations of $\mathrm{Zn}, \mathrm{Cr}, \mathrm{Cu}, \mathrm{As}, \mathrm{Cd}$, and $\mathrm{Pb}$. The spatial distribution, source, and potential ecological risk of these metals were determined. The results suggest a great spatial heterogeneity of heavy metals in the sediment of the studied rivers. Heavy metals had highest concentrations in the sediment of XR, especially midstream and downstream. A principal component analysis (PCA) and correlation analysis indicated that $\mathrm{Cd}$ and As were mainly from industrial wastewater and mineral mining, $\mathrm{Cr}$ came from natural process and agricultural activities, and $\mathrm{Zn}$ and $\mathrm{Cu}$ potentially from both. $\mathrm{Pb}$ was originated from atmospheric deposition and river inflow transportation. According to the geo-accumulation index $\left(\mathrm{I}_{\text {geo }}\right)$, enrichment factor $(\mathrm{EF})$, and risk index (RI) assessment, heavy metals pollution was highest in the sediment of $\mathrm{XR}$, and $\mathrm{Cd}$ was the main pollutant in the sediment of XR, presenting considerable potential ecological risk. This may contribute to heavy metal pollution in Dongting Lake. This paper provides a reference for the aquatic environmental management of heavy metals in Dongting Lake area and its tributaries.
\end{abstract}

Keywords: heavy metal; sediment; risk assessment; tributaries; Dongting Lake

\section{Introduction}

Aquatic systems enable hydrological cycling, climate regulation, and habitat provision for aquatic organisms. Heavy metal pollution in the aquatic environment has attracted global attention because of the environmental toxicity, persistence, and bioaccumulation of heavy metals, which can pose adverse effects on living beings and the entire ecosystem [1,2]. Sediment is considered as the largest pool of heavy metals in the aquatic environment $[3,4]$. About $99 \%$ of the heavy metals load in aquatic systems has been found to ultimately precipitate onto the sediment [5]. Heavy metal concentrations in the sediment are usually four or five times higher than that found in the overlying water [6]. Thus, sediment quality can reflect the heavy metal pollution status of the whole ecosystem. Consequently, it is of great importance to measure the amount of heavy metals in the sediment to provide information on the heavy metal contamination of the entire aquatic ecosystem.

Heavy metals enter aquatic ecosystem sediment via natural processes, including atmosphere deposition, rock weathering and erosion, and hydrodynamic alteration, as well as via anthropogenic activities, such as industrial wastewater discharge and agricultural fertilizer leaching [7]. With the 
rapid development of industrialization, urbanization, and agriculture, anthropogenic activities have become the main source of heavy metal pollution in the sediment of many rivers around the world. When the environmental factors of $\mathrm{pH}$, oxidation-reduction potential (Eh), and organic matter [7-9] change, the heavy metal in sediment may release into the overlying water. In addition, the flushing operation caused by flow may not only cause the resuspension of sediment, but also affect the spatial distribution of heavy metals in the sediment [10]. As well as the artificial replenishing activities of sediment that may result in the dispersion of pollutants (include heavy metals) in the sediment [11,12]. Accordingly, it is required to have a comprehensive assessment of the sediment quality, considering environmental changes.

Various studies have focused on the assessment of the extent of metal pollution using numerous analytical techniques based on heavy metal concentration and distribution patterns [13-15]. Ke et al. [16] assessed the ecological risk of the heavy metals $\mathrm{Cd}, \mathrm{As}, \mathrm{Cu}, \mathrm{Ni}, \mathrm{Pb}, \mathrm{Cr}$, and $\mathrm{Zn}$, with sediment quality guidelines (SQGs), geo-accumulation index $\left(\mathrm{I}_{\text {geo }}\right)$, potential ecological risk index (RI), and risk assessment code (RAC). Zahra et al. [9] determined the metal accumulation, distribution, and pollution status using the enrichment factor (EF), $\mathrm{I}_{g e o}$, and metal pollution index (MPI) of the Rawal Lake tributary. EF and $\mathrm{I}_{g e o}$ take into consideration the enrichment and pollution status of a single element; RI, SQG, and MPI take into consideration the combined effects of heavy metals, while RAC is mainly used to determine the speciation effect of heavy metals. Therefore, it is essential to determine the values of several combined indices for a comprehensive understanding of heavy metal pollution in the sediment.

Located south of the middle reaches of the Yangtze River, Dongting Lake is the second largest freshwater lake in China and has the Xiangjiang River (XR), Zishui River (ZR), Yuanjiang River (YR), and Lishui River (LR) as its main feeding tributaries [17]. The lake serves more than 600 million inhabitants and plays an important role in providing food and habitats for living beings, maintaining biodiversity, and controlling flooding [18]. Frequent mining and agricultural cultivation along the four tributaries have made them the primary source of heavy metals in Dongting Lake [19]. Presently, numerous studies have been conducted to evaluate the toxicity and ecological risk of heavy metals in the main body of Dongting Lake or part of its tributaries [17,20,21]. Nevertheless, there have been only a limited number of studies performed on a comprehensive comparison between the heavy metals in the sediments of the major tributaries listed above. Tributary rivers are the main source of pollutants for a lake and play an important role in maintaining a healthy lake ecosystem [9,22]. Therefore, this study is a comprehensive evaluation of heavy metals in the sediment of the four feeding tributary rivers in order to enable the efficient management of heavy metal pollution in Dongting Lake and its tributaries.

Given the importance of heavy metal pollution in sediment, this study was devoted to the analysis of the contamination of heavy metals $(\mathrm{Zn}, \mathrm{Cr}, \mathrm{Cd}, \mathrm{Pb}, \mathrm{As}$, and $\mathrm{Cu})$. The primary objectives of this study are as follows: (1) to investigate the spatial distribution of heavy metals in the surface sediment of the four tributaries by comparing them with various background values and previous studies; (2) to assess the level of contamination and potential ecological risk of heavy metals in sediments of the four tributaries using EF, Igeo, and RI; and (3) to explore the possible sources of heavy metals in the sediment of the four tributaries using correlation analysis and principal component analysis (PCA).

\section{Materials and Methods}

\subsection{Study Area}

Dongting Lake $\left(28^{\circ} 44^{\prime}-29^{\circ} 35^{\prime} \mathrm{N}, 111^{\circ} 53^{\prime}-113^{\circ} 05^{\prime} \mathrm{E}\right)$, the second largest freshwater lake in China, is located south of the middle reaches of the Yangtze River, and is strongly affected by the East Asian monsoon (Figure 1) [23]. The mean annual temperature is $16.4-7.0^{\circ} \mathrm{C}$ in the Dongting Lake area and the mean annual precipitation in the area is 1100-1400 mm/year, but the precipitation is mainly concentrated from April to June. Dongting Lake receives water mainly from the four 
tributaries, namely XR, ZR, YR, and LR, and then water flows into the Yangtze River at Chenglingji. The four tributaries, covering a drainage area of about $23.5 \mathrm{~km}^{2}$ [7], contribute about $68.3 \%$ of the runoff volume and $20 \%$ of the sediments of the Dongting Lake (Bulletin of the Yangtze River Sediments, 2006-2016). Previous studies have suggested that the four tributaries are polluted by heavy metals, with anthropogenic activities in their local environment as the main source responsible for pollutants $[17,24,25]$.

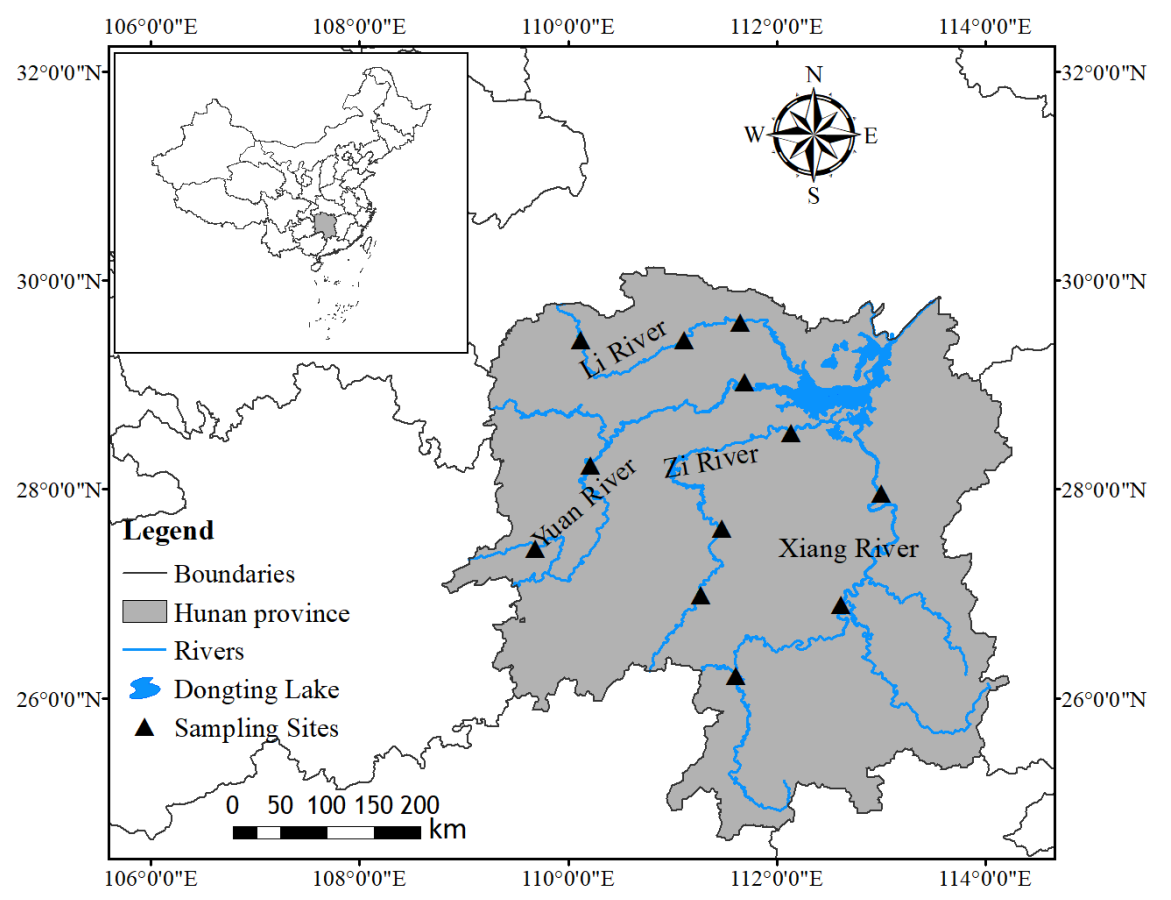

Figure 1. Study area and sampling locations in the four tributaries of Dongting Lake, China.

\subsection{Sample Collection}

Superficial sediment samples $(0-10 \mathrm{~cm})$ were collected in April (dry season) and in July (wet season) from upstream, midstream, and downstream portions of the four tributaries, in order to provide good area coverage (Figure 1). A composite surface sample (about $200 \mathrm{~g}$ ) at each site was collected because it is more chemically and biologically active than the deep layers, and more benthic organisms occupied this layer [16]. At each site, three samples were collected using a portable Ekman grab sampler, and were subsequently well mixed in situ, then placed in an acid-rinsed polyethylene plastic bag and sealed. The sediment samples were kept at $4{ }^{\circ} \mathrm{C}$ while being transferred to the laboratory for processing.

\subsection{Chemical Analysis}

The analysis of the heavy metal concentration was performed at the State Key Laboratory of Nanjing Institute of Geography and Limnology, The Chinese Academy of Science. The sediment samples were freeze-dried and homogenized by grinding, using an agate mortar and pestle to pass through an 100 mesh nylon sieve at room temperature. The samples $(0.5 \mathrm{~g})$ were then digested in $20 \mathrm{~mL}$ of a 1:1:2 guaranteed reagent $\mathrm{HNO}_{3}+\mathrm{HClO}_{4}+\mathrm{HF}$ in the Milestone ETHOS ONE digestion system for $10 \mathrm{~h}$. The digested samples were filtered $(0.45 \mu \mathrm{m}$ filter membrane $)$ and adjusted to a suitable volume. The total concentrations of $\mathrm{Cr}, \mathrm{Cu}, \mathrm{Zn}, \mathrm{Pb}, \mathrm{Cd}$, and As were analyzed using inductively coupled plasma-mass spectrometry (ICP-MS, 7700x, NYSE: A, America). The quality assurance and quality control of the analytical data were assessed in duplicate, with method blanks and standard reference materials. Three replicates were conducted for the determination of the total content of each 
heavy metal, and the total content of each heavy metal was expressed as the mean concentration of the replicates. The results were consistent with the reference values (Chinese national geo-standard [GBW-07333 and GBW-07314]), the differences of duplicated samples were within $\pm 10 \%$, and the measurement errors between the determined and certified values were less than $5 \%$.

All of the reagents were of supra quality and of analytical grade, and all of the solutions were prepared using ultra-pure water. All of the glassware and plastic were pre-cleaned by soaking in $\mathrm{HNO}_{3}(10 \%)$ for at least $48 \mathrm{~h}$, then rinsed repeatedly with ultra-pure water.

\subsection{Statistic Analysis}

An analysis of variance (ANOVA) was performed to assess the mean differences of the studied parameters among the rivers. A correlation analysis was conducted to ascertain whether or not a combined contamination among the heavy metals exists. The principal component analysis (PCA) is as an unsupervised pattern recognition method with varimax rotation and Kaiser normalization, which is widely used to reduce the related random environmental variables and to extract a small set of distinct variables (principal components [PCs]) that account for a large proportion of the total variance in the data. The non-normal data was transformed to normality using a logarithm or square root. Prior to PCA, the Kaiser-Meyer-Olkin (KMO) and Bartlett's sphericity tests were used to evaluate the validity of the original data, requiring that the KMO values should be more than 0.5 and that the Bartlett's sphericity tests be significant $(p<0.0001)$. The PCs with eigenvalues $>1$ were retained. All of the statistical analyses were conducted with $\mathrm{R}$ language software and all of the statistical methods were performed with a $95 \%$ confidence at $p<0.05$.

\subsection{Metal Assessment in Sediment}

The background value is of great importance in estimating the pollution degree and potential ecological risk of heavy metals in sediments. The shale and average crustal abundance data were typically used as background values [26]. In this paper, EF, $I_{g e o}$, and RI were calculated to estimate the contamination degree of the heavy metals in the surface sediment of the four rivers. Considering the regional discrepancies, the sediment background value of the heavy metals in the Dongting Lake drainage area was selected as the background value against which to evaluate the heavy metal pollution in the sediments of the four rivers [27].

\subsubsection{Calculation of Enrichment factor (EF)}

The EF was calculated to estimate the enrichment and possible anthropogenic impact of heavy metals on sediments using the following equation [9]:

$$
\mathrm{EF}=\frac{\left(C_{i} / C_{F e}\right)_{\text {Sediment }}}{\left(C_{i} / C_{F e}\right)_{\text {Background }}}
$$

where $\left(C_{i} / C_{F e}\right)_{\text {Sediment }}$ is the ratio of the concentration of a particular metal ' $i$ ' $\left(C_{i}\right)$ to the Fe concentration $C_{F e}$ in the sediment sample; and $\left(C_{i} / C_{F e}\right)_{B a c k g r o u n d}$ is the ratio of the background concentration of a particular metal ' $i$ ' $\left(C_{i}\right)$ to the reference background concentration of $F e$ $\left(C_{F e}\right)$, which is mainly used to decrease the influence of particle grain size on heavy metal contamination measurement.

\subsubsection{Calculation of Geo-Accumulation Index $\left(\mathrm{I}_{\text {geo }}\right)$}

The contamination caused by heavy metals in sediment can be assessed by $\mathrm{I}_{g e o}$ [28], as follows:

$$
\mathrm{I}_{\text {geo }}=\log _{2}\left[\frac{C_{i}}{1.5 B_{i}}\right]
$$


where $\mathrm{I}_{g e o}$ is the concentration of the measured heavy metal $i$, and $B_{i}$ is the geochemical background concentration of metal $i$. The corresponding background concentration of the heavy metals in the sediment of Dongting Lake [27] were used as $B_{i}$ in this paper. The factor 1.5 corresponds to the possible variation of the crustal contribution to sediment, mainly by weathering or erosion in the rivers.

\subsubsection{Calculation of Potential Ecological Risk (RI)}

RI was used to assess the potential ecological risk of heavy metal to the aquatic ecosystem, considering the toxicity and combined effects of each heavy metal, which $\mathrm{EF}$ and $\mathrm{I}_{\text {geo }}$ do not take into account. The calculation of the contamination factor $\left(C_{f}^{i}\right)$ and ecological risk factor $\left(E_{i}\right)$ of each heavy metal is the first step toward determining the RI. The following are the equations to measure $C_{f}^{i}$ and $E_{r}^{i}$, respectively:

$$
\begin{aligned}
C_{f}^{i} & =C_{i} / C_{b}^{i} \\
E_{r}^{i} & =C_{f}^{i} \cdot T_{r}^{i}
\end{aligned}
$$

where $C_{i}$ is the concentration of heavy metal $i$ in the sediment sample, and $C_{b}^{i}$ and $T_{r}^{i}$ are the preindustrial background value and toxic response factor in the sediment, respectively, obtained from the literature [29].

The RI was established by summing the $E_{r}^{i}$ of each heavy metal, as follows:

$$
\mathrm{RI}=\sum E_{r}^{i}
$$

The classes of EF, Igeo, and RI are listed in Table 1.

\begin{tabular}{|c|c|c|c|c|c|c|c|}
\hline EF Class $^{a}$ & $\begin{array}{l}\text { Sediment } \\
\text { Quality }\end{array}$ & $\mathbf{I}_{g e o}$ Class $^{\mathbf{b}}$ & $\begin{array}{l}\text { Sediment } \\
\text { Quality }\end{array}$ & $E_{r}^{i}$ Class & $\begin{array}{c}\text { Potential } \\
\text { Risk }\end{array}$ & RI Class $^{c}$ & $\begin{array}{c}\text { Ecological } \\
\text { Risk }\end{array}$ \\
\hline $\mathrm{EF}<1$ & No enrichment & $<0$ & Unpolluted & $E_{r}^{i}<40$ & Low & $\mathrm{RI}<150$ & Low \\
\hline $1 \leq \mathrm{EF}<3$ & $\begin{array}{c}\text { Minor } \\
\text { enrichment }\end{array}$ & $0-1$ & $\begin{array}{l}\text { Unpolluted to } \\
\text { moderately } \\
\text { polluted }\end{array}$ & $40 \leq E_{r}^{i}<80$ & Moderate & $150 \leq \mathrm{RI}<300$ & Moderate \\
\hline $3 \leq \mathrm{EF}<5$ & $\begin{array}{l}\text { Moderate } \\
\text { enrichment }\end{array}$ & $1-2$ & $\begin{array}{l}\text { Moderately } \\
\text { polluted }\end{array}$ & $80 \leq E_{r}^{i}<160$ & Considerable & $300 \leq \mathrm{RI}<600$ & Considerable \\
\hline $5 \leq \mathrm{EF}<10$ & $\begin{array}{l}\text { Moderately } \\
\text { severe } \\
\text { enrichment }\end{array}$ & $2-3$ & $\begin{array}{l}\text { Moderately to } \\
\text { highly polluted }\end{array}$ & $160 \leq E_{r}^{i}<320$ & High & $\mathrm{RI} \geq 600$ & Very high \\
\hline $10 \leq \mathrm{EF}<25$ & $\begin{array}{l}\text { Very severe } \\
\text { enrichment }\end{array}$ & $3-4$ & Highly polluted & $E_{r}^{i} \geq 320$ & Very high & & \\
\hline \multirow[t]{2}{*}{$\mathrm{EF} \geq 25$} & $\begin{array}{l}\text { Extremely } \\
\text { Severe } \\
\text { enrichment }\end{array}$ & $4-5$ & $\begin{array}{l}\text { Highly to very } \\
\text { highly polluted }\end{array}$ & & & & \\
\hline & & $>5$ & $\begin{array}{l}\text { Very highly } \\
\text { polluted }\end{array}$ & & & & \\
\hline
\end{tabular}

Table 1. The enrichment factor (EF), geo-accumulation index $\left(\mathrm{I}_{\text {geo }}\right)$, and risk index (RI) classes in relation to sediment quality.

\section{Results}

\subsection{Spatial Distribution of Heavy Metals}

The mean concentration of the heavy metals followed a decreasing ranking order of $\mathrm{Zn}-\mathrm{Pb}-\mathrm{Cr}-\mathrm{Cu}-\mathrm{As}-\mathrm{Cd}$, with values of $197 \mathrm{mg} / \mathrm{kg}$ for $\mathrm{Zn}, 71 \mathrm{mg} / \mathrm{kg}$ for Pb, $66 \mathrm{mg} / \mathrm{kg}$ for Cr, $42 \mathrm{mg} / \mathrm{kg}$ for $\mathrm{Cu}, 38 \mathrm{mg} / \mathrm{kg}$ for As, and $5.85 \mathrm{mg} / \mathrm{kg}$ for Cd (Table 2). All of the metals' concentration varied significantly among the rivers $(p<0.05$ ), except $\mathrm{Cr}$ (Figure 2). The $\mathrm{Zn}, \mathrm{Cu}$, and As concentrations were highest in XR $(374.45 \mathrm{mg} / \mathrm{kg}, 65.85 \mathrm{mg} / \mathrm{kg}$ and $84.70 \mathrm{mg} / \mathrm{kg})$, followed by ZR $(187.37 \mathrm{mg} / \mathrm{kg}$, 
$40.11 \mathrm{mg} / \mathrm{kg}$ and $30.59 \mathrm{mg} / \mathrm{kg})$, YR $(149.64 \mathrm{mg} / \mathrm{kg}, 37.50 \mathrm{mg} / \mathrm{kg}$ and $24.54 \mathrm{mg} / \mathrm{kg})$, and LR (78.42 mg/kg, $24.19 \mathrm{mg} / \mathrm{kg}$ and $13.93 \mathrm{mg} / \mathrm{kg}$ ). While the $\mathrm{Cr}, \mathrm{Cd}$, and $\mathrm{Pb}$ concentrations descended in the order of XR-YR-ZR-LR, with the highest concentrations of $87.31 \mathrm{mg} / \mathrm{kg}, 14.30 \mathrm{mg} / \mathrm{kg}$, and $106.08 \mathrm{mg} / \mathrm{kg}$ in $\mathrm{XR}$, respectively.

Table 2. Comparison of metals in sediment with different national and international guidelines and studies about rivers.

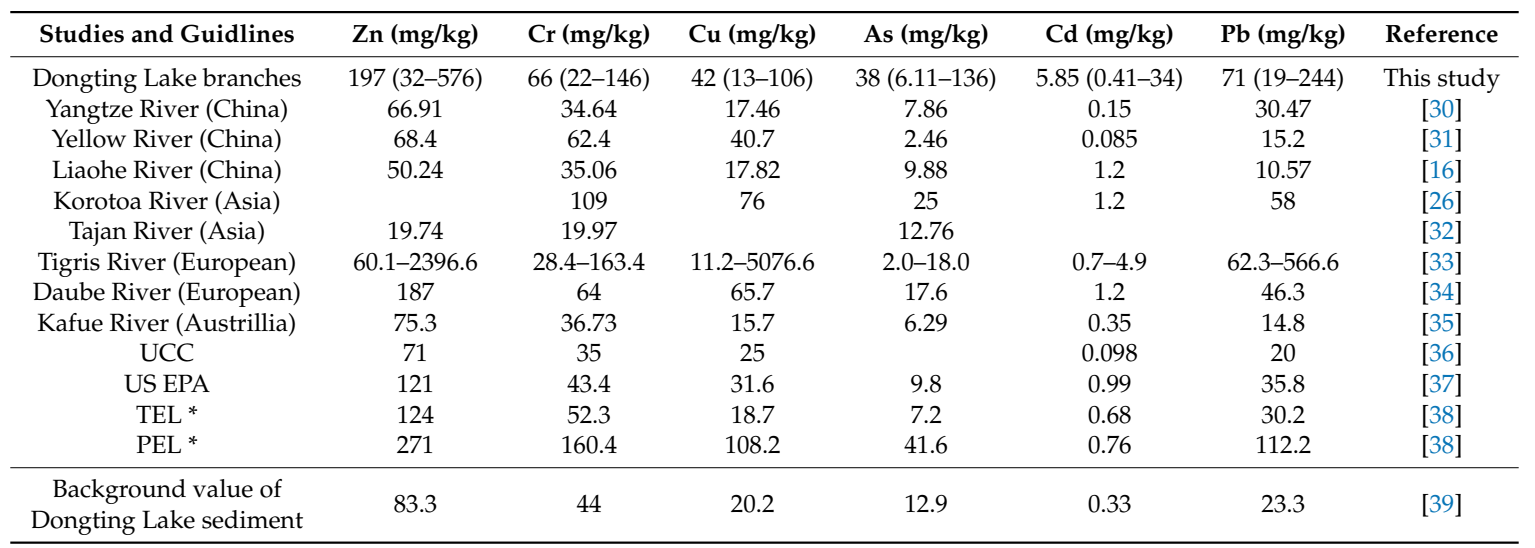

Note: * TEL represents threshold effects level; PEL represents the probable effects level. Adverse effects are expected to occur only rarely when the values of heavy metals are below the TEL; adverse biological effects can occasionally occur when the values are between the TEL and the PEL; adverse biological effects occur more frequently when the values exceed the PEL. TEL represents the concentration below which the adverse effects are expected to occur only rarely; PEL represents the concentration above which adverse effects are expected to occur frequently. UCC-upper continental crust; USEPA-United States Environmental Protection Agency.
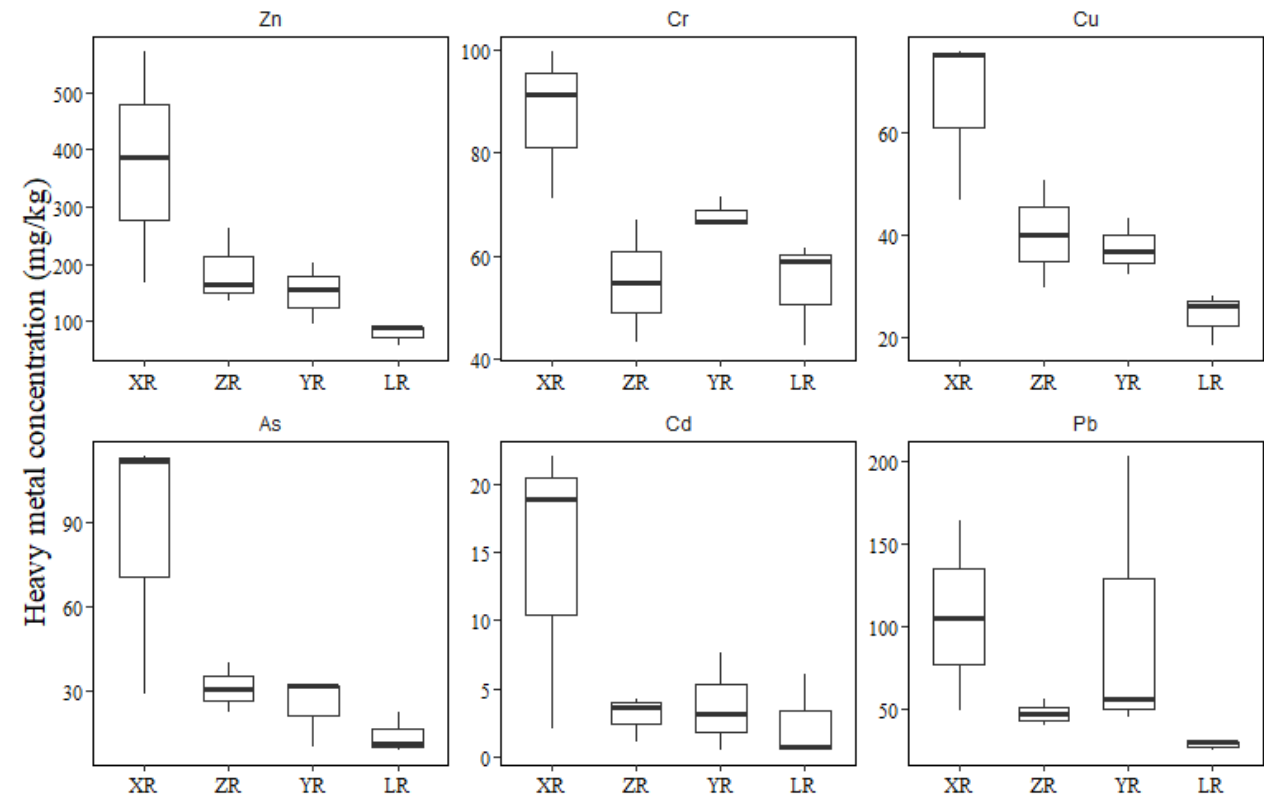

Figure 2. Heavy metal concentrations in the sediment of the four studied rivers. XR一Xiangjiang River; ZR-Zishui River; YR-Yuanjiang River; LR-Lishui River.

The heavy metals in the sediment of different sections of the rivers were not regularly distributed (Figure 3). In $\mathrm{XR}$, all of the metals, except $\mathrm{Cr}$, had higher concentrations in the midstream and downstream regions, especially As and Cd. The As concentrations in the midstream $(113.42 \mathrm{mg} / \mathrm{kg})$ and downstream $(111.77 \mathrm{mg} / \mathrm{kg})$ were more than 3.5 times higher than the concentrations upstream $(28.90 \mathrm{mg} / \mathrm{kg})$. The Cd values in the midstream $(22.04 \mathrm{mg} / \mathrm{kg})$ and downstream $(18.84 \mathrm{mg} / \mathrm{kg})$ regions were more than 11- and 9-fold higher than the upstream $(2.02 \mathrm{mg} / \mathrm{kg})$, respectively. The heavy metals 
were also present at a higher concentration midstream and downstream of LR, with the exception of $\mathrm{Cd}$, which had significantly higher values upstream $(6.00 \mathrm{mg} / \mathrm{kg})$. The $\mathrm{Zn}$, As, and Cd concentrations in $\mathrm{ZR}$ and $\mathrm{YR}$, as well as the $\mathrm{Cr}$ concentration in $\mathrm{ZR}$, were higher in the midstream and downstream regions. The $\mathrm{Pb}$ concentration was significantly higher in the upstream of $\mathrm{YR}$ and midstream of $\mathrm{ZR}$, while the $\mathrm{Cu}$ and $\mathrm{Cr}$ concentrations in YR were higher in the midstream region.
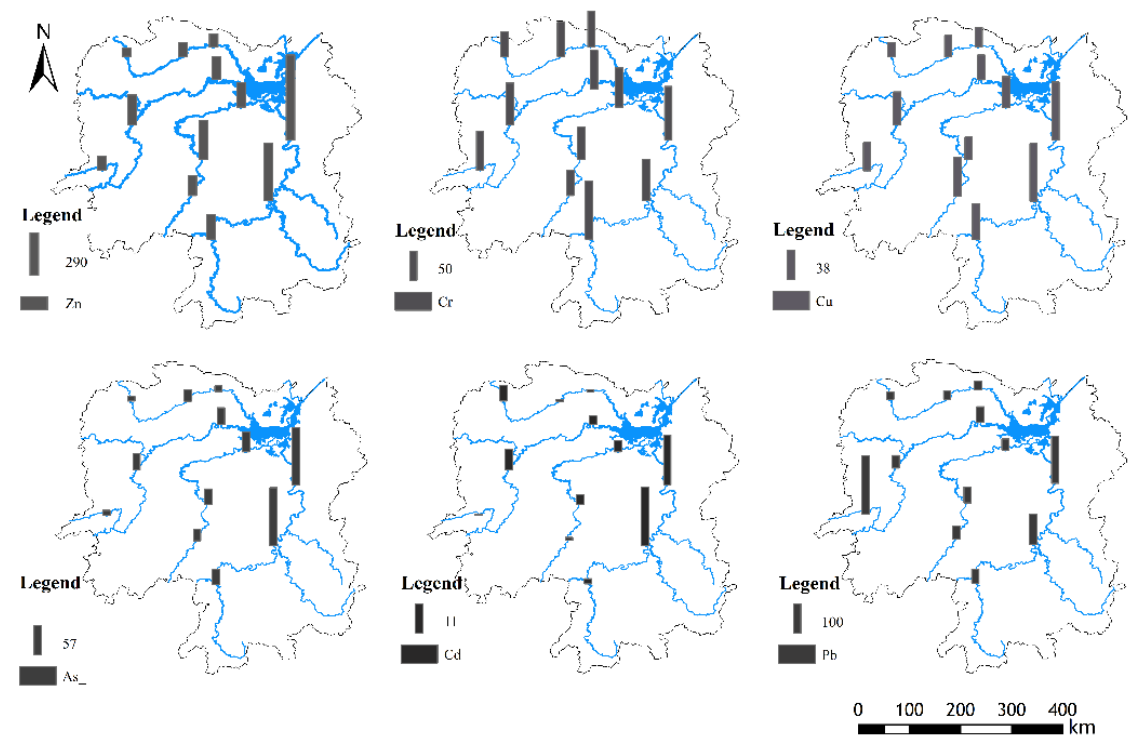

Figure 3. Heavy metal concentrations in different reaches of studied rivers (all metals in unit of $\mathrm{mg} / \mathrm{kg}$ ).

The mean concentrations of $\mathrm{Cd}, \mathrm{Pb}, \mathrm{As}, \mathrm{Zn}, \mathrm{Cu}$, and $\mathrm{Cr}$ were significantly higher than the background value of the Dongting Lake sediment, respectively, as well as the upper continental crust (UCC) values and the freshwater sediment screening benchmarks of the US EPA (United States Environmental Protection Agency), and the threshold effects level (TEL) (Table 2). Only the average concentration of $\mathrm{Cd}$ was more than 7.6 times higher than the probable effects level (PEL). In comparison with the concentrations of heavy metals reported in the sediments in other rivers in China and other countries, the $\mathrm{As}, \mathrm{Cd}$, and $\mathrm{Pb}$ concentration in the present study exceeded all of the the rivers, except that $\mathrm{Pb}$ was relatively lower than that in the sediment of the Tigris River; the $\mathrm{Zn}, \mathrm{Cu}$, and $\mathrm{Cr}$ concentrations were higher than some of the reported rivers.

\subsection{Risk Assessment of Heavy Metals}

To ascertain the degree of contamination and the possible sources (natural and anthropogenic sources) of heavy metals ( $\mathrm{Zn}, \mathrm{Cr}, \mathrm{Cu}, \mathrm{As}, \mathrm{Pb}$, and $\mathrm{Cd}), \mathrm{EF}, \mathrm{I}_{\text {geo }}$, and RI were established. Table 3 presents the EF values of heavy metals in the sediment. The mean EF values for Cd (14.24) were >10, while the other metals were in the range of 1-3. All of the EF values for Cd in the sediments of the four rivers were significantly higher than 1 and in the order of $E F(X R)=33.58>E F(Y R)=9.03>$ $\mathrm{EF}(\mathrm{ZR})=7.77>\mathrm{EF}(\mathrm{LR})=6.57$. These values indicate an extremely severe enrichment of Cd in $\mathrm{XR}$, and a severe enrichment of $\mathrm{Cd}$ in the other three rivers. The EF values for $\mathrm{Cd}$ were especially high in the midstream and downstream regions of XR (54.26 and 42.06, respectively) and ZR (10.34 and 10.40 , respectively), in addition to the midstream region of YR (17.83) and the upstream region of LR (15.79). In addition, $X R$ had the highest EF values of As, in the range of 5-10, and Zn, in the range of $3-5$, especially common in the midstream and downstream regions, indicating a moderately severe enrichment and moderate enrichment of these two metals, respectively. $\mathrm{Cu}$ and $\mathrm{Cr}$ had highest EF values in XR in the range of 1-3, while Pb had the highest EF values in YR (4.09), especially in the upstream region (8.87). 
In a similar pattern to the established EF values, $\mathrm{Cd}$ had the highest mean $\mathrm{I}_{g e o}$ value (2.31) compared with other metals, suggesting moderate to high levels of pollution in the river sediment (Table 4). Other metals had $\mathrm{I}_{g e o}$ values of $<1$ or $<0$, indicating an absence of pollution or minor levels of pollution in the sediment. The $\mathrm{Cd} \mathrm{I}_{g e o}$ values in the sediment of the four rivers can be ranked in order of XR $\left(\mathrm{I}_{\text {geo }}=4.14\right)>\mathrm{ZR}\left(\mathrm{I}_{g e o}=2.31\right)>\mathrm{YR}\left(\mathrm{I}_{g e o}=1.86\right)>\mathrm{LR}\left(\mathrm{I}_{g e o}=0.91\right)$. This indicates a high to very high pollution of $X R$ sediment, and un-polluted to minor pollution levels in other river sediments by $\mathrm{Cd}$. Moreover, $\mathrm{Cd}$ had a relatively higher $\mathrm{I}_{g e o}$ value in the sediment of the midstream and downstream regions of $\mathrm{XR}\left(\mathrm{I}_{\text {geo }}=5.21,5.20\right.$, respectively) and $\mathrm{ZR}\left(\mathrm{I}_{\text {geo }}=2.85,3.09\right.$, respectively), the midstream region of $\mathrm{YR}\left(\mathrm{I}_{g e o}=3.94\right)$, and the upstream region of $\mathrm{LR}\left(\mathrm{I}_{g e o}=2.21\right)$, as compared with other sections of rivers. The $\mathrm{I}_{g e o}$ values for As were also the highest in XR (1.74), especially in the midstream $\left(\mathrm{I}_{g e o}=2.55\right)$ and downstream $\left(\mathrm{I}_{g e o}=2.50\right)$ regions.

Table 5 shows the ecological risk factor $E_{r}^{i}$ of the individual heavy metals, and the potential ecological risk index (RI) of the combined heavy metals present in the sediments of the four rivers. The mean $E_{r}^{i}$ values of $\mathrm{Zn}, \mathrm{Cr}, \mathrm{Cu}$, and $\mathrm{Pb}$ were smaller than 40 , except $\mathrm{Cd}\left(E_{r}^{i}=175.64\right)$, suggesting a low ecological risk from these metals. Cd had highest $E_{r}^{i}$ values in the sediment of XR $\left(E_{r}^{i}=428.95\right)$, followed by $\mathrm{YR}\left(E_{r}^{i}=111.69\right), \mathrm{ZR}\left(E_{r}^{i}=89.75\right)$, and $\mathrm{LR}\left(E_{r}^{i}=72.18\right)$. The $E_{r}^{i}$ values were particularly higher in the midstream and downstream region of $\mathrm{XR}\left(E_{r}^{i}=661.18,565.21\right.$, respectively) and ZR $\left(E_{r}^{i}=109.82,126.79\right.$, respectively $)$, in the midstream region of $\mathrm{YR}\left(E_{r}^{i}=228.36\right)$, and upstream of LR $\left(E_{r}^{i}=179.97\right)$, than in other sections of the respective rivers. The metals in the sediment of all of the rivers present a low potential ecological risk, except for at XR $(R I=503.66)$, where they pose a considerable potential ecological risk. The potential ecological risk index values indicated that the metals in the sediment caused moderate potential ecological risk $(R I=213.097)$ overall.

Table 3. EF values of analyzed metals in river sediments. XR-Xiangjiang River; ZR-Zishui River; YR-Yuanjiang River; LR-Lishui River.

\begin{tabular}{|c|c|c|c|c|c|c|c|}
\hline Rivers & Section & $\mathrm{Zn}$ & $\mathrm{Cr}$ & $\mathrm{Cu}$ & As & $\mathrm{Cd}$ & $\mathbf{P b}$ \\
\hline \multirow[t]{3}{*}{$\mathrm{XR}$} & UP & 1.39 & 1.43 & 1.56 & 1.32 & 4.43 & 1.47 \\
\hline & MID & 4.02 & 1.38 & 3.18 & 8.33 & 54.26 & 3.89 \\
\hline & DOWN & 4.88 & 1.47 & 2.66 & 6.35 & 42.06 & 5.00 \\
\hline \multicolumn{2}{|c|}{ Average } & 3.43 & 1.43 & 2.47 & 5.33 & 33.58 & 3.45 \\
\hline \multirow[t]{3}{*}{ ZR } & UP & 1.34 & 0.79 & 2.13 & 1.38 & 2.58 & 1.61 \\
\hline & MID & 2.98 & 1.17 & 1.37 & 2.17 & 10.34 & 2.24 \\
\hline & DOWN & 1.60 & 1.24 & 1.61 & 2.50 & 10.40 & 1.37 \\
\hline \multicolumn{2}{|c|}{ Average } & 1.97 & 1.06 & 1.70 & 2.01 & 7.77 & 1.74 \\
\hline \multirow[t]{3}{*}{ YR } & UP & 1.13 & 1.45 & 1.81 & 0.74 & 1.46 & 8.87 \\
\hline & MID & 1.81 & 1.22 & 1.61 & 1.83 & 17.83 & 1.45 \\
\hline & DOWN & 1.54 & 1.25 & 1.32 & 2.05 & 7.80 & 1.95 \\
\hline \multicolumn{2}{|c|}{ Average } & 1.49 & 1.30 & 1.58 & 1.54 & 9.03 & 4.09 \\
\hline \multirow[t]{3}{*}{ LR } & UP & 0.66 & 0.95 & 0.88 & 0.63 & 15.79 & 1.00 \\
\hline & MID & 1.12 & 1.41 & 1.44 & 1.68 & 1.76 & 1.30 \\
\hline & DOWN & 1.09 & 1.45 & 1.32 & 0.84 & 2.16 & 1.31 \\
\hline \multicolumn{2}{|c|}{ Average } & 0.96 & 1.27 & 1.21 & 1.05 & 6.57 & 1.20 \\
\hline \multicolumn{2}{|c|}{ total average } & 1.96 & 1.26 & 1.74 & 2.48 & 14.24 & 2.62 \\
\hline
\end{tabular}


Table 4. $\mathrm{I}_{g e o}$ of the analyzed metals in the river sediment.

\begin{tabular}{cccccccc}
\hline Rivers & Section & $\mathbf{Z n}$ & $\mathbf{C r}$ & $\mathbf{C u}$ & $\mathbf{A s}$ & $\mathbf{C d}$ & $\mathbf{P b}$ \\
\hline \multirow{4}{*}{ XR } & Upstream & 0.38 & 0.42 & 0.57 & 0.18 & 2.03 & 0.47 \\
& Midstream & 1.52 & -0.04 & 1.18 & 2.55 & 5.21 & 1.47 \\
& Downstream & 2.19 & 0.47 & 1.32 & 2.50 & 5.20 & 2.23 \\
\hline \multirow{4}{*}{ ZR } & Average & 1.36 & 0.28 & 1.02 & 1.74 & 4.14 & 1.39 \\
& Upstream & 0.13 & -0.65 & 0.69 & 0.18 & 1.02 & 0.40 \\
& Midstream & 1.00 & -0.29 & -0.10 & 0.52 & 2.85 & 0.66 \\
& Downstream & 0.40 & 0.02 & 0.40 & 1.03 & 3.09 & 0.17 \\
\hline \multirow{4}{*}{ YR } & Average & 0.51 & -0.30 & 0.33 & 0.57 & 2.32 & 0.41 \\
& Upstream & -0.41 & -0.05 & 0.29 & -1.01 & -0.07 & 2.52 \\
& Midstream & 0.66 & 0.10 & 0.48 & 0.67 & 3.94 & 0.33 \\
& Downstream & 0.23 & 0.01 & 0.09 & 0.66 & 1.71 & 0.60 \\
\hline \multirow{4}{*}{ LR } & Average & 0.16 & 0.02 & 0.29 & 0.10 & 1.86 & 1.15 \\
& Upstream & -1.31 & -0.82 & -0.80 & -1.18 & 2.21 & -0.52 \\
& Midstream & -0.50 & -0.17 & -0.14 & -0.34 & 0.09 & -0.32 \\
& Downstream & -0.55 & -0.14 & -0.27 & -0.94 & 0.44 & -0.28 \\
\hline \multirow{6}{*}{ Average } & -0.79 & -0.37 & -0.40 & -0.82 & 0.91 & -0.37 \\
\hline & Total average & 0.31 & -0.09 & 0.31 & 0.40 & 2.31 & 0.64 \\
\hline
\end{tabular}

Table 5. The potential ecological risk index of analyzed metals in river sediments.

\begin{tabular}{|c|c|c|c|c|c|c|c|c|}
\hline \multirow{2}{*}{ Rivers } & \multirow{2}{*}{ Section } & \multicolumn{6}{|c|}{ ER } & \multirow{2}{*}{ RI } \\
\hline & & $\mathrm{Zn}$ & $\mathrm{Cr}$ & $\mathrm{Cu}$ & As & $\mathrm{Cd}$ & $\mathbf{P b}$ & \\
\hline \multirow[t]{3}{*}{$\mathrm{XR}$} & Upper & 0.95 & 2.21 & 4.68 & 19.27 & 60.47 & 3.50 & 91.08 \\
\hline & Middle & 2.21 & 1.58 & 7.51 & 75.61 & 661.18 & 7.49 & 755.57 \\
\hline & Lower & 3.26 & 2.03 & 7.57 & 74.51 & 565.21 & 11.74 & 664.33 \\
\hline \multicolumn{2}{|c|}{ Average } & 2.14 & 1.94 & 6.59 & 56.46 & 428.95 & 7.58 & 503.66 \\
\hline \multirow[t]{3}{*}{ ZR } & Upper & 0.78 & 0.96 & 5.06 & 14.67 & 32.65 & 3.29 & 57.41 \\
\hline & Middle & 1.49 & 1.22 & 2.96 & 20.16 & 109.82 & 3.98 & 139.63 \\
\hline & Lower & 0.94 & 1.49 & 4.01 & 26.37 & 126.79 & 2.81 & 162.40 \\
\hline \multicolumn{2}{|c|}{ Average } & 1.07 & 1.22 & 4.01 & 20.40 & 89.75 & 3.36 & 119.81 \\
\hline \multirow[t]{3}{*}{ YR } & Upper & 0.54 & 1.48 & 3.69 & 6.65 & 14.30 & 14.54 & 41.19 \\
\hline & Middle & 1.15 & 1.59 & 4.34 & 20.96 & 228.36 & 3.20 & 259.59 \\
\hline & Lower & 0.88 & 1.47 & 3.23 & 21.47 & 92.42 & 3.94 & 123.42 \\
\hline \multicolumn{2}{|c|}{ Average } & 0.86 & 1.51 & 3.75 & 16.36 & 111.69 & 7.23 & 141.40 \\
\hline \multirow[t]{3}{*}{ LR } & Upper & 0.32 & 0.94 & 1.83 & 5.77 & 179.97 & 1.75 & 190.58 \\
\hline & Middle & 0.52 & 1.31 & 2.82 & 14.79 & 16.19 & 2.13 & 37.77 \\
\hline & Lower & 0.51 & 1.37 & 2.61 & 7.29 & 20.36 & 2.08 & 34.21 \\
\hline \multicolumn{2}{|c|}{ Average } & 0.45 & 1.21 & 2.42 & 9.28 & 72.18 & 1.99 & 87.52 \\
\hline \multicolumn{2}{|c|}{ Total average } & 1.13 & 1.47 & 4.19 & 25.63 & 175.64 & 5.04 & 213.10 \\
\hline
\end{tabular}

\subsection{Source Identification for Heavy Metal Pollutants}

The correlation among heavy metals may indicate the same source and similar migration pattern of these elements [16]. The lack of any significant correlation signifies that the heavy metals may originate from different sources and be controlled by multiple factors. The Pearson correlation of the analyzed metals is presented in Table $6 . \mathrm{Zn}, \mathrm{Cr}, \mathrm{Cu}, \mathrm{As}$, and $\mathrm{Cd}$ were significantly correlated with each other (For example: Zn-Cr: $r=0.548, p<0.05$; Zn-Cu: $r=0.779, p<0.05$; Zn-As: $r=0.772$, $p<0.05 ; \mathrm{Zn}-\mathrm{Cd}: r=0.785, p<0.05 ; \mathrm{Cr}-\mathrm{Cu}: r=0.745, p<0.05)$, with the exception of $\mathrm{Cr}$, which was not 
significantly correlated with either $\mathrm{As}$ or $\mathrm{Cd}$. Moreover, $\mathrm{Pb}$ was not significantly correlated with any metals, except $\operatorname{Cr}(r=0.456, p<0.05)$.

Table 6. Correlation of analyzed metals in river sediments.

\begin{tabular}{ccccccc}
\hline Variables & $\mathbf{Z n}$ & $\mathbf{C r}$ & $\mathbf{C u}$ & $\mathbf{A s}$ & $\mathbf{C d}$ & $\mathbf{P b}$ \\
\hline $\mathrm{Zn}$ & 1 & & & & & \\
$\mathrm{Cr}$ & $\mathbf{0 . 5 4 8}$ & 1 & & & & \\
$\mathrm{Cu}$ & $\mathbf{0 . 7 7 9}$ & $\mathbf{0 . 7 4 5}$ & 1 & & & \\
$\mathrm{As}$ & $\mathbf{0 . 7 7 2}$ & 0.104 & $\mathbf{0 . 4 3 3}$ & 1 & & \\
$\mathrm{Cd}$ & $\mathbf{0 . 7 8 5}$ & 0.167 & $\mathbf{0 . 4 9 5}$ & $\mathbf{0 . 9 0 1}$ & 1 & \\
$\mathrm{~Pb}$ & 0.397 & $\mathbf{0 . 4 5 6}$ & 0.304 & 0.192 & 0.181 & 1 \\
\hline
\end{tabular}

Note: The number in bold indicates correlation is significant at $p<0.05$ level.

To clarify the origin of the heavy metals in the studied area, PCA was chosen as the analysis tool. Table 7 shows the component matrix and variance of the metals in the studied rivers extracted by eigenvalue $>1$. Figure 4 shows the variation diagram in rotated space with the first two components as axes. Two components were extracted, explaining $81.946 \%$ of the total variance, which is therefore in accordance with the regulation that the principal components should account for at least $75 \%$ of the total variance [40]. Component 1 showed the general loading of surface sediments with heavy metals. It was heavily loaded with $\mathrm{Cd}$, As, and Zn, while being moderately loaded with $\mathrm{Cu}$, explaining 58.85\% of the total variance with an eigenvalue of 3.531. Component 2 explained $23.09 \%$ of the total variance, having a high positive loading with $\mathrm{Cr}, \mathrm{Cu}$, and $\mathrm{Pb}$, and moderately loading with $\mathrm{Zn}$.

Table 7. Loading corresponding to the first two components for surface sediments of the four rivers.

\begin{tabular}{ccc}
\hline \multirow{2}{*}{ Metals } & \multicolumn{2}{c}{ Components } \\
\cline { 2 - 3 } & $\mathbf{1}$ & $\mathbf{2}$ \\
$\mathrm{Zn}$ & $\mathbf{0 . 7 8 7}$ & $\mathbf{0 . 5 5 5}$ \\
$\mathrm{Cr}$ & 0.049 & $\mathbf{0 . 9 3 4}$ \\
$\mathrm{Cu}$ & $\mathbf{0 . 4 5 4}$ & $\mathbf{0 . 7 6 2}$ \\
$\mathrm{As}$ & $\mathbf{0 . 9 6 4}$ & 0.062 \\
$\mathrm{Cd}$ & $\mathbf{0 . 9 5 9}$ & 0.115 \\
$\mathrm{~Pb}$ & 0.074 & $\mathbf{0 . 6 7 5}$ \\
Eigenvalues & 3.531 & 1.386 \\
$\%$ total variance & 58.854 & 23.092 \\
$\%$ cumulative total variance & 58.854 & 81.946 \\
\hline
\end{tabular}

Note: significant factor loadings are bold faced.

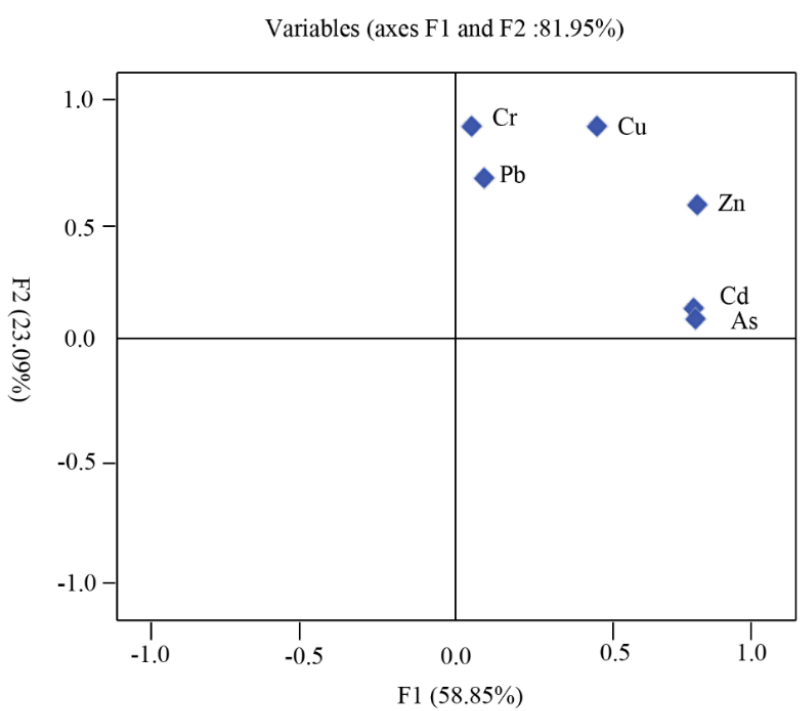

Figure 4. Plot of the loading of the first two rotated principle components. 


\section{Discussion}

Heavy metals are a special group that may mainly be derived from anthropogenic activities, with some contribution from natural sources [41]. In the present study, concentrations of $\mathrm{Zn}, \mathrm{Cu}$, As, $\mathrm{Cd}$, and $\mathrm{Pb}$ were significantly higher in $\mathrm{XR}$ than other rivers, while significantly lower in LR than other rivers, especially in the midstream and downstream regions of the two rivers. These results indicate that heavy metals in the sediment of the four rivers had a high degree of spatial heterogeneity. Taking the similarity in climate and background values of these rivers into consideration, anthropogenic activities, such as urbanization, industry, agriculture, aquaculture, and tourism development, may be main factors in the spatial differences in the heavy metal concentrations in the sediment [42]. Hunan Province is rich in non-ferrous metals, with high levels of mining, mineral processing, and smelting, contributing to the high concentrations distributed in the midstream and downstream region of XR [18,43-45]. In addition, many large cities, such as Xiangtan, Zhuzhou, and Changsha, are also located in the midstream and downstream regions of XR [46]. This urbanization and mineral utilization might explain the high concentration of heavy metals in the sediment of XR. Moreover, the large drainage area of XR may bring non-point source pollutants [47]. The construction of a dam in the upstream may enhance the flushing of the river [48], and this may also contribute to the relatively higher heavy metal concentrations in the middle and lower reaches of XR. While the phosphorous chemical production in the upstream region of YR might contribute to the significantly higher $\mathrm{Pb}$ concentrations observed, as compared with other sections.

The criteria for heavy metal values in the sediments have been developed by international and national governments, to assess their pollution level and ensure sediment security. In the present study, the concentrations of $\mathrm{Zn}, \mathrm{Cd}, \mathrm{Pb}, \mathrm{As}, \mathrm{Zn}, \mathrm{Cu}$, and $\mathrm{Cr}$ were higher than the UCC, US EPA, TEL, and background value for Dongting Lake sediment. This finding indicates that heavy metals in the sediment might cause adverse effects on the river systems studied. This was corresponded with previous studies that reported serious levels of heavy metal pollution in the sediment of Dongting Lake and its tributaries [21,49-52]. This was especially true for $\mathrm{Cd}$, which was 60-fold higher than the UCC and US EPA guidelines and 7.6-fold higher than the PEL. It is of note that Hunan Province had the highest ranked level of production of $\mathrm{Cd}, \mathrm{As}, \mathrm{Cr}$, and $\mathrm{Pb}$ in China for many years, as well as the highest relative industrial discharge via wastewater [17]. Furthermore, about 1.7 million tons of fertilizer and pesticides containing $\mathrm{Cd}, \mathrm{Cr}, \mathrm{Pb}$, As, and other metals, are used annually in the Dongting Lake drainage region [53]. Therefore, anthropogenic activities surrounding the studied area might be the main reason for the heavy metal pollution in the sediment.

Heavy metal pollution of the surface sediment has been one of the most serious problems facing the Dongting Lake. Ma et al. [54] assessed heavy metals in the sediment of the six major freshwater lakes in China, namely Dongting Lake, Poyang Lake, Hongze Lake, Chaohu Lake, Taihu Lake, and Hongsi Lake, and the results indicated that Dongting Lake shows the highest ecological risk. Some studies compared the heavy metal concentration in the sediment of Dongting lake and the river inlets, the results indicated that the heavy metal concentration in the sediment of the inlet of the four rivers is higher than other parts of Dongting Lake [55]. In this study, the mean concentration of Zn, $\mathrm{Pb}, \mathrm{Cd}$, and As were higher than those found in Dongting Lake [21]. These results suggested that the four rivers may be the main sources of heavy metals in the sediment of Dongting Lake. However, the relatively lower metal concentration at the outlet of Chenglingji indicates that the metals that have flown in from rivers are diluted in the Dongting Lake [56]. The construction of The Three Gorge Dam decreases the sand contribution of Yangtze River to Dongting Lake, and increases the flushing of the Dongting Lake sediment, this may resuspend the sediment into the overlying water, thus decreasing heavy metal contents in the sediment of Dongting Lake [48].

In this study, $\mathrm{Cd}$ had high $\mathrm{EF}(>10), \mathrm{I}_{g e o}(>2)$, and $E_{r}^{i}(>150)$ values compared with other metals, indicating that the $\mathrm{Cd}$ pollution levels were moderate to high in river sediments and presents a high ecological risk. This corresponds with previous reports that $\mathrm{Cd}$ was the main pollutants of all of the heavy metals, and had the highest ecological risk in the sediment of Dongting Lake area $[21,50,52]$. 
The $\mathrm{Cd}$ in the sediment of the Dongting Lake drainage is mainly in exchangeable and carbonate form, this may contribute to the high ecological risk $[50,51,57]$. What is more, the sensitivity of $\mathrm{Cd}$ to low $\mathrm{pH}$, Eh, and OM (organic matter), may also partly contribute to its high ecological risk in the sediment of studied rivers [57]. This needs further validation in future study. The RI values for heavy metals in sediments indicate that heavy metals present a considerable ecological risk in XR (RI >300), while they pose a low ecological risk in the other three rivers $(R I<150)$. This was corresponding with the high ecological risk of heavy metals in the sediment of southern and eastern Dongting Lake, while a low ecological risk of western Dongting Lake [56]. Furthermore, the significantly higher EF ( $>25), \mathrm{I}_{\text {geo }}(>4)$, and $E_{r}^{i}(>150)$ values indicate that $\mathrm{Cd}$ contributed the most to the high ecological risk of sediments in $\mathrm{XR}$, especially in the midstream and downstream regions. Considering the severe toxicity caused by $\mathrm{Cd}$ to the respiratory system, nervous system, immune system, and DNA [58], special measures are urgently needed to control both point and non-point pollutants, and to ensure the safety of aquatic ecosystem, especially XR.

Using the correlation and PCA analysis, pairs of heavy metals were correlated with each other, with $\mathrm{As}$ and $\mathrm{Cd}$, and $\mathrm{Cr}$ and $\mathrm{Pb}$, presenting similar variations, respectively, suggesting a high level of consistency in their sources. Furthermore, $\mathrm{Cu}$ and $\mathrm{Zn}$ were significantly correlated with $\mathrm{As}, \mathrm{Cd}$, and $\mathrm{Cr}$, as well as having a high loading in both the first and second components. This suggested that $\mathrm{Zn}$ and $\mathrm{Cu}$ originated from a mutual source to $\mathrm{Cr}$, As, and $\mathrm{Cd}$. The mean concentrations of $\mathrm{Cd}$ and As were 17.7- and 3.0-fold higher than the background value of the Dongting Lake sediment, respectively, indicating an anthropogenic source for the two metals. This is corroborated by the moderate to high levels of $\mathrm{Cd}$ pollution, while the As pollution was absent to moderate, as derived by the assessment of EF and $I_{g e o}$. According to the Hunan Statistical Year Book (2017), the content of $\mathrm{Cd}$ and As in the sewage discharged from Hunan Province accounts for $40 \%$ and $10.3 \%$ of the total discharge across China, respectively. Studies have illustrated that XR is the area most polluted by heavy metals in China, with the heavy metal pollution mainly derived from industrial manufacturing and refined mineral mining $[21,59,60]$. Therefore, the significantly higher concentration of $\mathrm{Cd}$ and As observed in the sediment of XR, compared with the other three rivers, indicates that As and Cd may be mainly produced by industrial wastewater and mineral mining processes. According to the $\mathrm{I}_{\text {geo }}, \mathrm{EF}$, and RI values established, the studied sediment was not polluted by $\mathrm{Cr}$, with $\mathrm{Pb}$ pollution absent to moderate. Therefore, $\mathrm{Cr}$ and $\mathrm{Pb}$ may be partly produced by natural sources, however, the distinct spatial distribution patterns indicate that these two metals may derive from different sources. Cr concentrations showed low spatial variation, which suggests a non-point agricultural origin. According to the Huan statistical Year Book (2017), 118,661 tons of pesticides were used in Hunan Province in 2017, with most of these pesticides containing metals including Cr. Thus, Cr may mainly originate from natural sources and agricultural activities [21]. $\mathrm{Zn}$ and $\mathrm{Cu}$ originate from both the sources of $\mathrm{Cd} / \mathrm{As}$ and $\mathrm{Cr}$. Atmospheric and river inflows transport $\mathrm{Pb}$ from industrial wastewater and sewage discharge $[25,61]$.

This study comprehensively assessed the pollution status of heavy metals in the sediment of main tributaries of Dongting Lake. This provides a reference for aquatic environmental management of heavy metals in Dongting Lake drainage. However, further study is needed for a deeper understanding of the heavy metals in the sediment of studied rivers. Firstly, it is the bioavailability rather than the total concentration decides the toxicity of heavy metals. Therefore, further studies should be conducted on speciation of heavy metals in the sediments of these tributaries to confirm their toxicity. Secondly, although environmental factors of $\mathrm{pH}$, organic matter, and Eh were mentioned in this study, no data were measured and no further correlation were analyzed between these factors and heavy metal concentrations. More studies should be conducted to make clear the relationship between environmental factors and heavy metal speciation in the sediment of the four rivers. Lastly, this study confirmed that heavy metals in the sediment of the four rivers are important sources of Dongting Lake. Deeper studies should be conducted to configure to what extent these heavy metals from the four rivers contribute to the Dongting Lake sediment. 


\section{Conclusions}

The identification and quantification of heavy metal pollution in the sediment of tributaries in Dongting Lake is of great importance for the maintenance of a healthy ecosystem. Concentrations of the studied heavy metals exceeded the criteria values of UCC, US EPA, and the background value of the Dongting Lake sediment. The highest exceedance was $\mathrm{Cd}$, which had concentration about 60 -fold higher than the guideline values. The concentrations of the studied heavy metals were highest in XR, especially in the midstream and downstream regions. The PCA and correlation analysis indicates that $\mathrm{Cd}$ and As originated mainly from industrial wastewater and mineral mining; $\mathrm{Cr}$ originated from natural processes and agricultural activities; $\mathrm{Zn}$ and $\mathrm{Cu}$ may originate from both sources of $\mathrm{Cd} / \mathrm{As}$ and $\mathrm{Cr}$; and $\mathrm{Pb}$ was mainly from atmospheric deposition and river inflow transportation. According to the $\mathrm{I}_{g e o}, \mathrm{EF}$, and RI assessment, the heavy metal pollution of the sediment was highest at $\mathrm{XR}$, presenting considerable potential ecological risk. Cd was the main pollutant in the sediment of XR, which contributes significantly to the very high ecological risk level. Therefore, special attention should be paid to heavy metals in the sediment of $\mathrm{XR}$, especially $\mathrm{Cd}$ pollution, in order to keep the whole ecosystem healthy. Furthermore, in this study, anthropogenic activity is the main reason for heavy metal pollution, thus, further field investigation should be conducted for the source identification, and then measures should be taken to control the pollutants from the source. This work provides basic information for the heavy metal distribution, source, and pollution status, and serves as a reference for heavy metal pollution management in the sediment of Dongting Lake area.

Author Contributions: J.X., Y.C., and X.W. conceived of the original outline for this study and designed the sampling points. J.L. and B.L. helped in the data processing and result analysis. L.Z. performed the analysis with constructive discussions. J.X. wrote the paper. All of the authors read and approved the final manuscript.

Funding: This research was funded by the STS (Science and Technology Service Network Initiative) Project of theChinese Academy of Sciences (KFJ-STS-ZDTP-011) and the Basic Work of Science and Technology (Grants 2012FY111800-03, 2013FY111802).

Acknowledgments: We thank Poyang Laboratory for the Wetland Ecosystem Research, and the Chinese Academy of Science for the assistance in the water samples collection.

Conflicts of Interest: The authors declare no conflict of interest.

\section{References}

1. Hulscher, T.E.M.T.; Mol, G.A.J.; Lüers, F. Release of metals from polluted sediments in a shallow lake: Quantifying resuspension. Hydrobiologia 1992, 235-236, 97-105. [CrossRef]

2. Phillips, D.P.; Human, L.R.D.; Adams, J.B. Wetland plants as indicators of heavy metal contamination. Mar. Pollut. Bull. 2015, 92, 227-232. [CrossRef] [PubMed]

3. Hasegawa, H.; Rahman, M.A.; Kitahara, K.; Itaya, Y.; Maki, T.; Ueda, K. Seasonal changes of arsenic speciation in lake waters in relation to eutrophication. Sci. Total Environ. 2010, 408, 1684-1690. [CrossRef] [PubMed]

4. Hu, B.Q.; Li, G.G.; Li, J.; Bi, J.Q.; Zhao, J.T.; Bu, R.Y. Spatial distribution and ecotoxicological risk assessment of heavy metals in surface sediments of the southern Bohai Bay, China. Environ. Sci. Pollut. Res. 2013, 20, 4099-4110. [CrossRef] [PubMed]

5. Peng, J.F.; Song, Y.H.; Yuan, P.; Cui, X.Y.; Qiu, G.L. The remediation of heavy metals contaminated sediment. J. Hazard. Mater. 2009, 161, 633-640. [CrossRef] [PubMed]

6. Yuan, G.L.; Liu, C.; Chen, L.; Yang, Z. Inputting history of heavy metals into the inland lake recorded in sediment profiles: Poyang lake in China. J. Hazard. Mater. 2011, 185, 336-345. [CrossRef] [PubMed]

7. Zhang, C.; Yu, Z.G.; Zeng, G.M.; Jiang, M.; Yang, Z.Z.; Cui, F.; Zhu, M.Y.; Shen, L.Q.; Hu, L. Effects of sediment geochemical properties on heavy metal bioavailability. Environ. Int. 2014, 73, 270-281. [CrossRef] [PubMed]

8. Suthar, S.; Nema, A.K.; Chabukdhara, M.; Gupta, S.K. Assessment of metals in water and sediments of Hindon River, India: Impact of industrial and urban discharges. J. Hazard. Mater. 2009, 171, 1088-1095. [CrossRef] [PubMed] 
9. Zahra, A.; Hashmi, M.Z.; Malik, R.N.; Ahmed, Z. Enrichment and geo-accumulation of heavy metals and risk assessment of sediments of the Kurang Nallah-Feeding tributary of the Rawal Lake Reservoir, Pakistan. Sci. Total Environ. 2014, 470-471, 925. [CrossRef] [PubMed]

10. Schleiss, A.J.; Franca, M.J.; Juez, C.; De Cesare, G. Reservoir sedimentation. J. Hydraul. Res. 2016, 54, 595-614. [CrossRef]

11. Juez, C.; Thalmann, M.; Schleiss, A.J.; Franca, M.J. Morphological resilience to flow fluctuations of fine sediment deposits in bank lateral cavities. Adv. Water Resour. 2018, 115, 44-59. [CrossRef]

12. Juez, C.; Battisacco, E.; Schleiss, A.J.; Franca, M.J. Assessment of the performance of numerical modeling in reproducing a replenishment of sediments in a water-worked channel. Adv. Water Resour. 2016, 92, 10-22. [CrossRef]

13. Rajeshkumar, S.; Liu, Y.; Zhang, X.Y.; Ravikumar, B.; Bai, G.; Li, X.Y. Studies on seasonal pollution of heavy metals in water, sediment, fish and oyster from the Meiliang Bay of Taihu Lake in China. Chemosphere 2017, 191, 626-638. [CrossRef] [PubMed]

14. Ekere, N.; Yakubu, N.; Ihedioha, J. Ecological risk assessment of heavy metals and polycyclic aromatic hydrocarbons in sediments of rivers niger and benue confluence, Lokoja, Central Nigeria. Environ. Sci. Pollut. Res. 2017, 24, 18966-18978. [CrossRef] [PubMed]

15. Cagnin, R.C.; Quaresma, V.S.; Chaillou, G.; Franco, T.; Bastos, A.C. Arsenic enrichment in sediment on the eastern continental shelf of Brazil. Sci. Total Environ. 2017, 607-608, 304-316. [CrossRef] [PubMed]

16. Ke, X.; Gui, S.; Huang, H.; Zhang, H.; Wang, C.; Guo, W. Ecological risk assessment and source identification for heavy metals in surface sediment from the Liaohe River protected area, China. Chemosphere 2017, 175, 473-481. [CrossRef] [PubMed]

17. Sun, G.X.; Wang, X.J.; Hu, Q.H. Using stable lead isotopes to trace heavy metal contamination sources in sediments of Xiangjiang and Lishui Rivers in China. Environ. Pollut. 2011, 159, 3406-3410. [CrossRef] [PubMed]

18. Chen, X.; Mcgowan, S.; Xu, L.; Zeng, L.H.; Yang, X.D. Effects of hydrological regulation and anthropogenic pollutants on Dongting Lake in the Yangtze floodplain. Ecohydrology 2016, 9, 315-325. [CrossRef]

19. Yao, Z.G. Comparison between bcr sequential extraction and geo-accumulation method to evaluate metal mobility in sediments of Dongting Lake, central China. Chin. J. Oceanol. Limnol. 2008, 26, 14-22. [CrossRef]

20. Zhang, Y.; Tian, Y.; Shen, M.; Zeng, G. Heavy metals in soils and sediments from Dongting Lake in China: Occurrence, sources, and spatial distribution by multivariate statistical analysis. Environ. Sci. Pollut. Res. 2018, 25, 1-10. [CrossRef] [PubMed]

21. Li, F.; Huang, J.; Zeng, G.; Yuan, X.; Li, X.; Liang, J.; Wang, X.; Tang, X.; Bai, B. Spatial risk assessment and sources identification of heavy metals in surface sediments from Dongting Lake, middle China. J. Geochem. Explor. 2013, 132, 75-83. [CrossRef]

22. Li, C.; Wang, P.; Chen, B.; Li, Y. Spatial distribution and pollution source of dissolved metals in the Ganjiang River of Lake Poyang Basin. J. Lake Sci. 2018, 30, 139-149.

23. Pourabadehei, M.; Mulligan, C.N. Effect of the resuspension technique on distribution of the heavy metals in sediment and suspended particulate matter. Chemosphere 2016, 153, 58-67. [CrossRef] [PubMed]

24. Chai, L.; Li, H.; Yang, Z.; Min, X.; Liao, Q.; Liu, Y.; Men, S.; Yan, Y.; Xu, J. Heavy metals and metalloids in the surface sediments of the Xiangjiang River, Hunan, China: Distribution, contamination, and ecological risk assessment. Environ. Sci. Pollut. Res. 2016, 24, 1-12. [CrossRef] [PubMed]

25. Fang, X.; Peng, B.; Zhang, K.; Zeng, D.; Kuang, X.; Wu, B.; Tu, X.; Song, Z.; Xiao, Y.; Yang, Z. Geochemistry of major and trace elements in sediments from inlets of the Xiangjiang and Yuanjiang River to Dongting Lake, China. Environ. Earth Sci. 2018, 77, 1-16. [CrossRef]

26. Islam, M.S.; Ahmed, M.K.; Raknuzzaman, M.; Habibullah-Al-Mamun, M.; Islam, M.K. Heavy metal pollution in surface water and sediment: A preliminary assessment of an urban river in a developing country. Ecol. Indic. 2015, 48, 282-291. [CrossRef]

27. Liu, J.; Liang, J.; Yuan, X.; Zeng, G.; Yuan, Y.; Wu, H.; Huang, X.; Liu, J.; Hua, S.; Li, F. An integrated model for assessing heavy metal exposure risk to migratory birds in wetland ecosystem: A case study in Dongting Lake Wetland, China. Chemosphere 2015, 135, 14-19. [CrossRef] [PubMed]

28. Muller, G. Index of geoaccumulation in sediments of the rhine river. Geojournal 1969, 2, 108-118.

29. Hakanson, L. An ecological risk index for aquatic pollution control. A sedimentological approach. Water Res. 1980, 14, 975-1001. [CrossRef] 
30. Han, D.; Cheng, J.; Hu, X.; Jiang, Z.; Mo, L.; Xu, H.; Ma, Y.; Chen, X.; Wang, H. Spatial distribution, risk assessment and source identification of heavy metals in sediments of the Yangtze River Estuary, China. Mar. Pollut. Bull. 2017, 115, 141-148. [CrossRef] [PubMed]

31. Yan, N.; Liu, W.; Xie, H.; Gao, L.; Han, Y.; Wang, M.; Li, H. Distribution and assessment of heavy metals in the surface sediment of Yellow River, China. J. Environ. Sci. 2016, 39, 45-51. (In English) [CrossRef] [PubMed]

32. Alahabadi, A.; Malvandi, H. Contamination and ecological risk assessment of heavy metals and metalloids in surface sediments of the Tajan River, Iran. Mar. Pollut. Bull. 2018, 133, 741-749. [CrossRef] [PubMed]

33. Varol, M. Assessment of heavy metal contamination in sediments of the Tigris River (Turkey) using pollution indices and multivariate statistical techniques. J. Hazard. Mater. 2011, 195, 355-364. [CrossRef] [PubMed]

34. Woitke, P.; Wellmitz, J.; Helm, D.; Kube, P.; Lepom, P.; Litheraty, P. Analysis and assessment of heavy metal pollution in suspended solids and sediments of the river Danube. Chemosphere 2003, 51, 633-642. [CrossRef]

35. M'Kandawire, E.; Choongo, K.; Yabe, J.; Mwase, M.; Saasa, N.; Nakayama, S.M.M.; Bortey-Sam, N.; Blindauer, C.A. Sediment metal contamination in the Kafue River of Zambia and ecological risk assessment. Bull. Environ. Contam. Toxicol. 2017, 99, 108-116. [CrossRef] [PubMed]

36. Taylor, S.R.; Mclennan, S.M. The continental crust: Its composition and evolution, an examination of the geochemical record preserved in sedimentary rocks. J. Geol. 1985, 94, 632-633.

37. US EPA. Epa Region iii btag. Freshwater Sediment Screening Benchmarks. Available online: https:// www.epa.gov/sites/production/files/2015-09/documents/r3_btag_fw_sediment_benchmarks_8-06.pdf (accessed on 15 April 2018).

38. Macdonald, D.D.; Ingersoll, C.G.; Berger, T.A. Development and evaluation of consensus-based sediment quality guidelines for freshwater ecosystems. Arch. Environ. Contam. Toxicol. 2000, 39, 20-31. [CrossRef] [PubMed]

39. Li, J.; Zeng, B.W.; Yao, Y.Y.; Zhang, L.C.; Qiu, C.Q.; Qian, X.Z. Study on the water environment background value of Dongting Lake system. Environ. Sci. 1986, 4, 62-68.

40. Loska, K.; Wiechuła, D. Application of principal component analysis for the estimation of source of heavy metal contamination in surface sediments from the Rybnik Reservoir. Chemosphere 2003, 51, 723-733. [CrossRef]

41. Li, Z.Y.; Ma, Z.W.; van der Kuijp, T.J.; Yuan, Z.W.; Huang, L. A review of soil heavy metal pollution from mines in China: Pollution and health risk assessment. Sci. Total Environ. 2014, 468, 843-853. [CrossRef] [PubMed]

42. Wang, X.L.; Zhang, L.; Zhao, Z.H.; Cai, Y.J. Heavy metal pollution in reservoirs in the hilly area of southern China: Distribution, source apportionment and health risk assessment. Sci. Total Environ. 2018, 634, 158-169. [CrossRef] [PubMed]

43. Zhang, Q.; Li, Z.; Zeng, G.; Li, J.; Fang, Y.; Yuan, Q.; Wang, Y.; Ye, F. Assessment of surface water quality using multivariate statistical techniques in red soil hilly region: A case study of Xiangjiang watershed, China. Environ. Monit. Assess. 2009, 152, 123-131. [CrossRef] [PubMed]

44. Mao, L.; Mo, D.; Guo, Y.; Fu, Q.; Yang, J.; Jia, Y. Multivariate analysis of heavy metals in surface sediments from lower reaches of the Xiangjiang River, southern China. Environ. Earth Sci. 2013, 69, 765-771. [CrossRef]

45. Liu, J.J. The Characterisitics Research of Heavy Metals Pollution in Sediment of the Xiangjiang River. Bachelor's Thesis, Xiangtan University, Xiangtan City, Hunan Province, China, 2016.

46. Zeng, G.; Zhang, C.; Huang, G.; Yu, J.; Wang, Q.; Li, J.; Xi, B.; Liu, H. Adsorption behavior of bisphenol a on sediments in Xiangjiang River, central-south china. Chemosphere 2006, 65, 1490-1499. [CrossRef] [PubMed]

47. Qin, Y.W.; Han, C.N.; Zhang, L.; Zheng, B.H.; Cao, W. Distribution of heavy metals among surface water, suspended solids and surface sediments in hengyang section of Xiangjiang River. Acta Sci. Circum. 2012, 32, 2836-2844.

48. Zhou, Y.; Li, J.; Zhang, Y.; Zhang, X.; Li, X. Enhanced lakebed sediment erosion in Dongting Lake induced by the operation of the three gorges reservoir. J. Geogr. Sci. 2015, 25, 917-929. [CrossRef]

49. Zeng, D.; Peng, B.; Zhang, K.; Fang, X.; Tan, C.; Kuang, X.; Wu, B.; Tu, X. Characteristics and assessment of heavy metal contamination in bed sediments from inlet areas of the Lishui River to Dongting Lake. Acta Sci. Circum. 2017, 37, 3480-3488.

50. Xiao, Y.; Peng, B.; Yang, Z.; Xie, W.; Fang, X.; Zeng, D. Speciation of heavy metals in riverbed sediments of heavy pollution section of the lowermost of the Xiangjiang River. Environ. Chem. 2017, 36, 1977-1986. 
51. Liu, J.; Xu, Y.; Cheng, Y.; Zhao, Y.; Pan, Y.; Fu, G.; Dai, Y. Occurrence and risk assessment of heavy metals in sediments of the Xiangjiang River, China. Environ. Sci. Pollut. Res. 2017, 24, 1-13. [CrossRef] [PubMed]

52. Zhang, G.G.; Tian, Q.; Guo, J. Heavy metal ecological risk of surface sediments in Dongting Lake and its tread. Asian J. Ecotoxicol. 2015, 10, 184-191. [CrossRef] [PubMed]

53. Liu, J.Y. Study of Heavy Metal Ecological Risk and Exposure to Waterfowl in Dongting Lake wetland. Master's Degree, Hunan University, Changsha, China, 2014.

54. Ma, Z.; Chen, K.; Yuan, Z.; Bi, J.; Huang, L. Ecological risk assessment of heavy metals in surface sediments of six major chinese freshwater lakes. J. Environ. Qual. 2013, 42, 341-350. [CrossRef] [PubMed]

55. Li, F.; Huang, J.H.; Zeng, G.M.; Huang, X.L.; Li, X.D.; Liang, J.; Wu, H.P.; Wang, X.Y.; Bai, B. Integrated source apportionment, screening risk assessment, and risk mapping of heavy metals in surface sediments: A case study of the Dongting Lake, middle China. Hum. Ecol. Risk Assess. 2014, 20, 1213-1230. [CrossRef]

56. Zhu, Y.L.; Jiang, J.H.; Sun, Z.D.; Huang, Q.; Wang, H.J.; Zhou, Y.K. Character and assessment of heavy metals in the sediments from Lake Dongting. J. Lake Sci. 2008, 20, 77-85.

57. Hu, C.; Deng, Z.-M.; Xie, Y.-H.; Chen, X.-S.; Li, F. The risk assessment of sediment heavy metal pollution in the east Dongting Lake wetland. J. Chem. 2015, 15, 1-8. [CrossRef]

58. Singh, A.; Singh, D.R.; Yadav, H.K. Impact and assessment of heavy metal toxicity on water quality, edible fishes and sediments in lakes: A review. Trends. Biosci. 2017, 10, 1551-1560.

59. Xu, Y.F.; Wu, Y.; Han, J.G.; Li, P.P. The current status of heavy metal in lake sediments from China: Pollution and ecological risk assessment. Ecol. Evol. 2017, 7, 5454-5466. [CrossRef] [PubMed]

60. Peng, B.; Tang, X.; Yu, C.; Tan, C.; Yin, C.; Yang, G.; Liu, Q.; Yang, K.; Tu, X. Geochemistry of trace metals and $\mathrm{Pb}$ isotopes of sediments from the lowermost Xiangjiang River, Hunan Province (P. R. China): Implications on sources of trace metals. Environ. Earth Sci. 2011, 64, 1455-1473. [CrossRef]

61. Dai, L.; Wang, L.; Li, L.; Liang, T.; Zhang, Y.; Ma, C.; Xing, B. Multivariate geostatistical analysis and source identification of heavy metals in the sediment of Poyang Lake in China. Sci. Total Environ. 2017, 621, 1433-1444. [CrossRef] [PubMed] 